\title{
THE
}

\section{A New Method of Interpreting the Valois Tapestries, through a History of Catherine de Médicis}

Pascal-François Bertrand

Pamela J. Warner

University of Rhode Island, pwarner@mail.uri.edu

Follow this and additional works at: https://digitalcommons.uri.edu/art_facpubs

Part of the History of Art, Architecture, and Archaeology Commons

Terms of Use

All rights reserved under copyright.

\section{Citation/Publisher Attribution}

Bertrand, Pascal-François. "A New Method of Interpreting the Valois Tapestries, through a History of Catherine de Médicis." Translated by Pamela J. Warner. Studies in the Decorative Arts 14 (2006): 27-52. Available at: http://dx.doi.org/10.1086/studdecoarts.14.1.40663287

This Article is brought to you for free and open access by the Art and Art History at DigitalCommons@URI. It has been accepted for inclusion in Art and Art History Faculty Publications by an authorized administrator of DigitalCommons@URI. For more information, please contact digitalcommons-group@uri.edu. 


\section{A New Method of Interpreting the Valois Tapestries, through a History of Catherine de Médicis}

In 1959, Frances A. Yates published the results of her research on the Valois tapestries, made in Brussels toward the end of the sixteenth century and today held in Florence. This prestigious ensemble comprises eight large pieces featuring fine workmanship and bright and lively colors, enhanced with gold and silver. ${ }^{1}$ According to the English historian, William of Orange had the tapestries executed at the moment when François-Hercule d'Alençon-d'Anjou, the last son of Catherine de Médicis and Henri II of France (of the Valois dynasty), overturned the power of Philip II of Spain in Holland, took the title of the duc de Brabant, and made his entry into Antwerp (1582). Yates asserted that William then had the tapestries delivered to the queen mother by Dutch ambassadors who were eager to renew their alliance with her third son, King Henri III. Yates's study, regarded as the definitive work on this set of hangings, is a good example of an impressive intellectual scaffolding resting on the most fragile of hypotheses, which have been transformed since their first writing into certitudes. Objections expressed by Jean Coural (1972), Roy Strong (1973), and Léon de Groër (1989), among others, have done little to weaken this study's authority. ${ }^{2}$

Coural observed a fundamental flaw in Yates's proposal, which claims that the series was woven in Antwerp, whereas the mark of the city of Brussels is affixed to the edge of six of the eight pieces, and two of the unidentified weavers' monograms can also be seen there. ${ }^{3}$ Strong remarked that the tapestries' originality lay in the presence of identifiable portraits in their foregrounds, interpreted until then as simple intermediaries between the festival scenes represented in the backgrounds and the viewer. He added that the tapestries could not be later than 1581, the date of the "magnificent" wedding of Anne d'Arques, duc de Joyeuse, to Marguerite de Lorraine, half-sister of the wife of Henri III, which was celebrated with the famous Ballet comique de la reine published in 1582, ${ }^{4}$ because no reference to it is made in the festivals represented in the weavings. De Groër moved the dating back even further, believing that the tapestries were commissioned around 1575 by the queen mother or

Pascal-François Bertrand is Professor of Art History at the Université Michel de Montaigne, Bordeaux 3. 


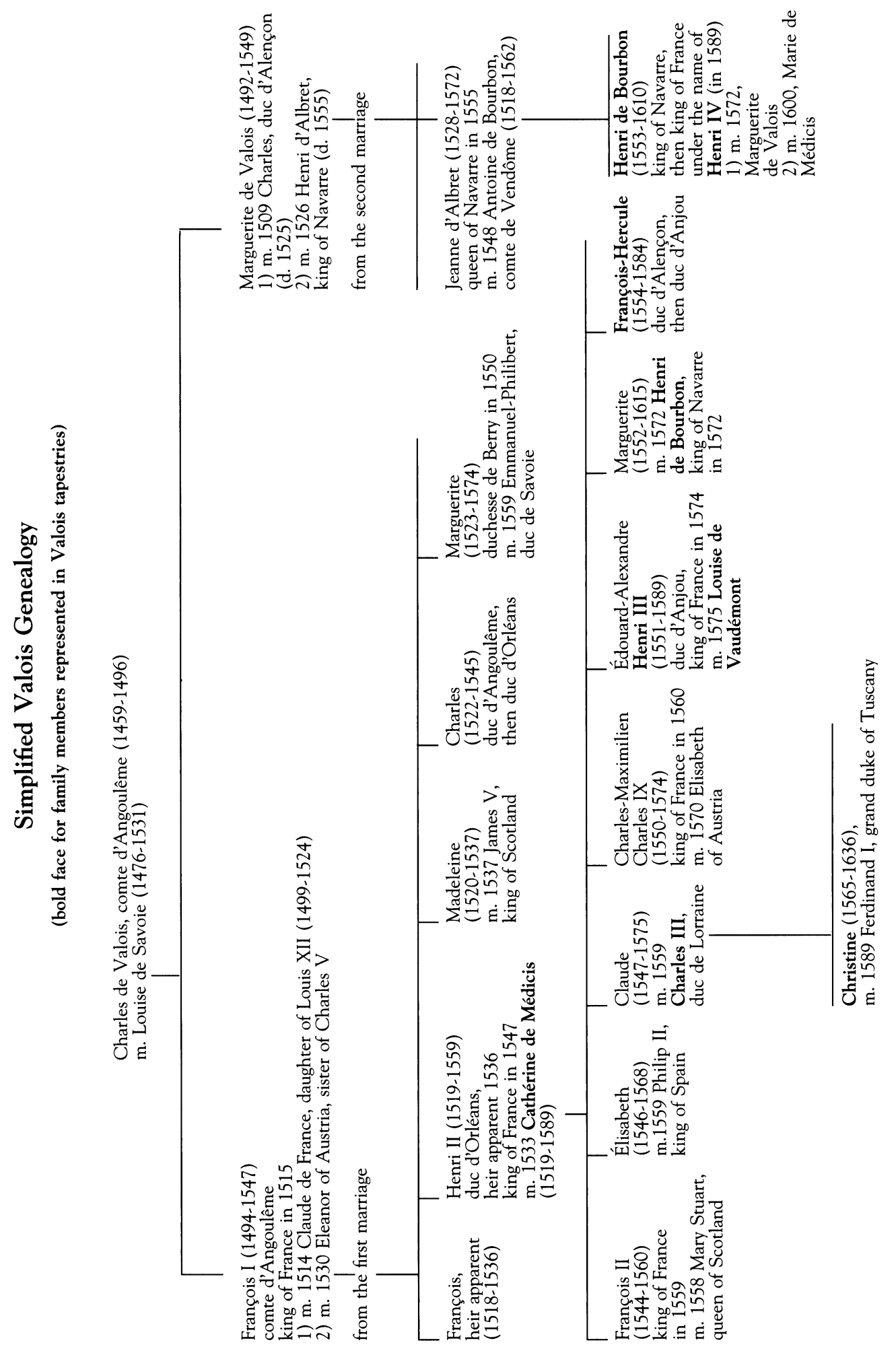


by someone in her close entourage because Catherine de Médicis appears in all of the tapestries except one (given her superstitious nature and her interest in magic and astrology, to appear in all would have been inauspicious). De Groër presented four observations in support of this date: all of the members of the royal family represented in the hanging were living when the tapestries were executed (none of the queen's dead children are shown); the faces of figures represented in the foreground correspond to portraits executed around 1575, such as that of Louise de Vaudémont, who, in February of that year, had just married Henri III; ${ }^{5}$ the costumes reflect the fashions of the 1570s, in particular the mediumsized ruff and the tall velvet hat, decorated on the front with jewels and small feathers, worn tilted back to the rear of the head; and finally-a weighty argument-none of the figures wears the chain of the Order of the Holy Spirit, founded by Henri III in $1578 .^{6}$

From this initial overview of the critics, it seems that almost nothing is known for certain about this tapestry series, which was inventoried in Florence in 1589 among the goods brought from France by Christine de Lorraine. It was Cecilia Lisi and Jean Ehrmann who thought they recognized it in the mention of a gold tapestry à figure, et fregio à grottesche et altro (with figures and a border of grotesques and more), presented by Catherine de Médicis with two other luxurious ensembles to her favorite granddaughter, Christine de Lorraine, perhaps on the occasion of her marriage to the grand duke of Tuscany, Ferdinand $\mathrm{I} .{ }^{7}$ While the dimensions given in the inventory correspond with those of the Valois tapestries, the formula used to describe the tapestry à figure is most laconic. Furthermore, if it is accepted that the series inventoried in 1589 is the same as the one in Florence today, the description also indicates that the meaning of the set had been lost by the time this gift was recorded, a gift made relatively quickly after the weaving of the ensemble (whether it is dated to 1575 or $1582-1585$ ).

There are two further questions: what is the subject of the Valois series and what is its meaning? In order to respond, it is necessary to investigate the nature of the relationship between the motifs represented in the tapestries (the portraits in the foregrounds and the festival scenes in the backgrounds), the initial function of the hangings, and finally the conditions in which this masterpiece was produced.

\section{The Multivalent Subject of the Tapestries}

It is known how much a work's title influences perception of it and orients its meaning. In the second half of the sixteenth century, a work 
FIGURE 1 (facing page)

Carrousel des chevaliers bretons et irlandais à Bayonne (Tournament). Brussels tapestry, unidentified atelier, c. 1575. Wool, silk, gold, and silver, $391 \times 611 \mathrm{~cm}$. Figs. 1-8 are all Galleria degli Uffizi, on deposit Palazzo Pitti, Ministero dei Beni e le Attività Culturali, Florence. Photo: Casa Editrice Sillabe, Livorno. of art could be intended to have more than one meaning. Since they aroused the interest of historians in the early twentieth century, the works in Florence have generally been called the "Valois tapestries," or sometimes the "Fêtes des Valois." 8 These fairly vague denominations, which reflect the notion of a lost meaning, mark at the same time the beginning of an interpretation, centered on the identity of the life-sized portraits of the royal family in the early years of Henri III's reign (figures represented laterally across the foreground of the hangings) and also on the identification of the grandiose and costly extravaganzas of the reign of Charles IX represented in the background. (For a simplified genealogy of the Valois dynasty, see p. 29.)

Among the members of the royal family, the queen mother, Catherine de Médicis, can be recognized first of all, in mourning, a dwarf at her feet, in the Carrousel des chevaliers bretons et irlandais à Bayonne (Tournament) (Fig. 1; titles in parentheses are those used by Frances Yates). To her right stands her daughter Marguerite de Valois and her daughter's spouse, Henri de Navarre, in profile. Catherine's daughter is also represented two more times in the series. She appears with her husband, to the left in the Fête nautique sur l'Adour (Whale) (Fig. 4), and there, between the two of them, stands Charles III, duc de Lorraine and widower of Claude de Valois, second daughter of Catherine de Médicis, who died in 1575, several days before the wedding of Henri III to Louise de Vaudémont. Marguerite de Valois also appears a third time, to the right in the Mascarade de l'éléphant (Elephant) (Fig. 5), between her brother FrançoisHercule d'Alençon and a young, unidentified man. Catherine's two living sons each appear twice. Henri III, her favorite son, is shown alone, wearing antique costume, about to mount a horse in the Jeu de la quintaine (Quintain) (Fig. 2), and with his wife, Louise de Vaudémont, in the right foreground of the Attaque de l'ile devant le château de Fontainebleau (Fontainebleau) (Fig. 3). Louise de Vaudémont appears again, to the right, in the Carrousel des chevaliers bretons et irlandais à Bayonne (Fig. 1), across from the queen mother and her daughter Marguerite, accompanied by a man and two other women. One of these last figures, seen from the back, was identified as possibly her half-sister, Marguerite de Lorraine, who, in 1581, married Anne, duc de Joyeuse, whose wedding, as cited above, was the occasion of the famous Ballet comique de la reine published in 1582. Finally François-Hercule d'Alençon, who was already seen with his sister Marguerite, stands holding a lance in his hand, to the right in the Combat à la barrière (Barriers) (Fig. 6). ${ }^{9}$

The background scenes recall the finest hours of the court of Catherine de Médicis, attesting to the magnificence and generosity of the 


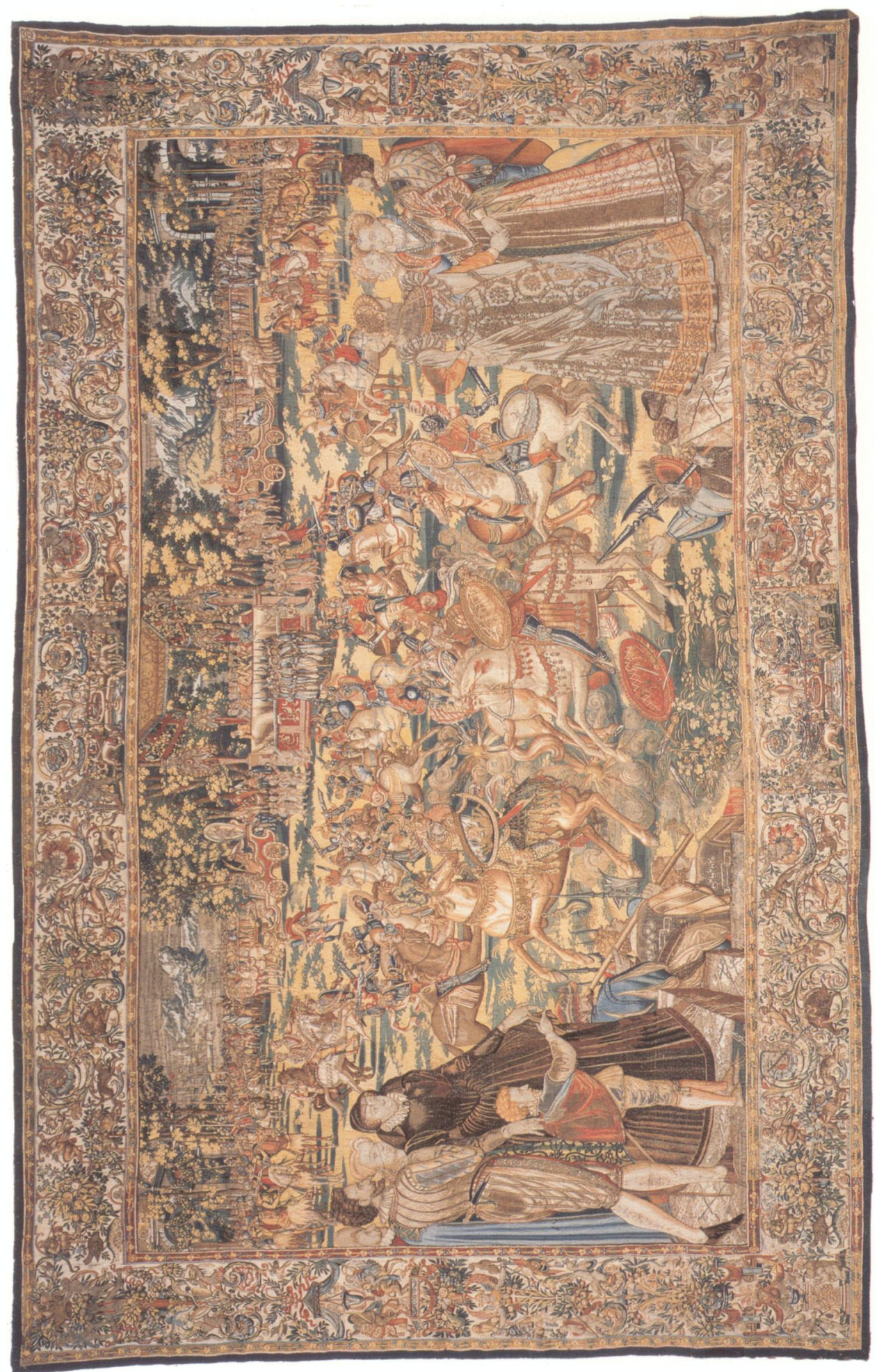




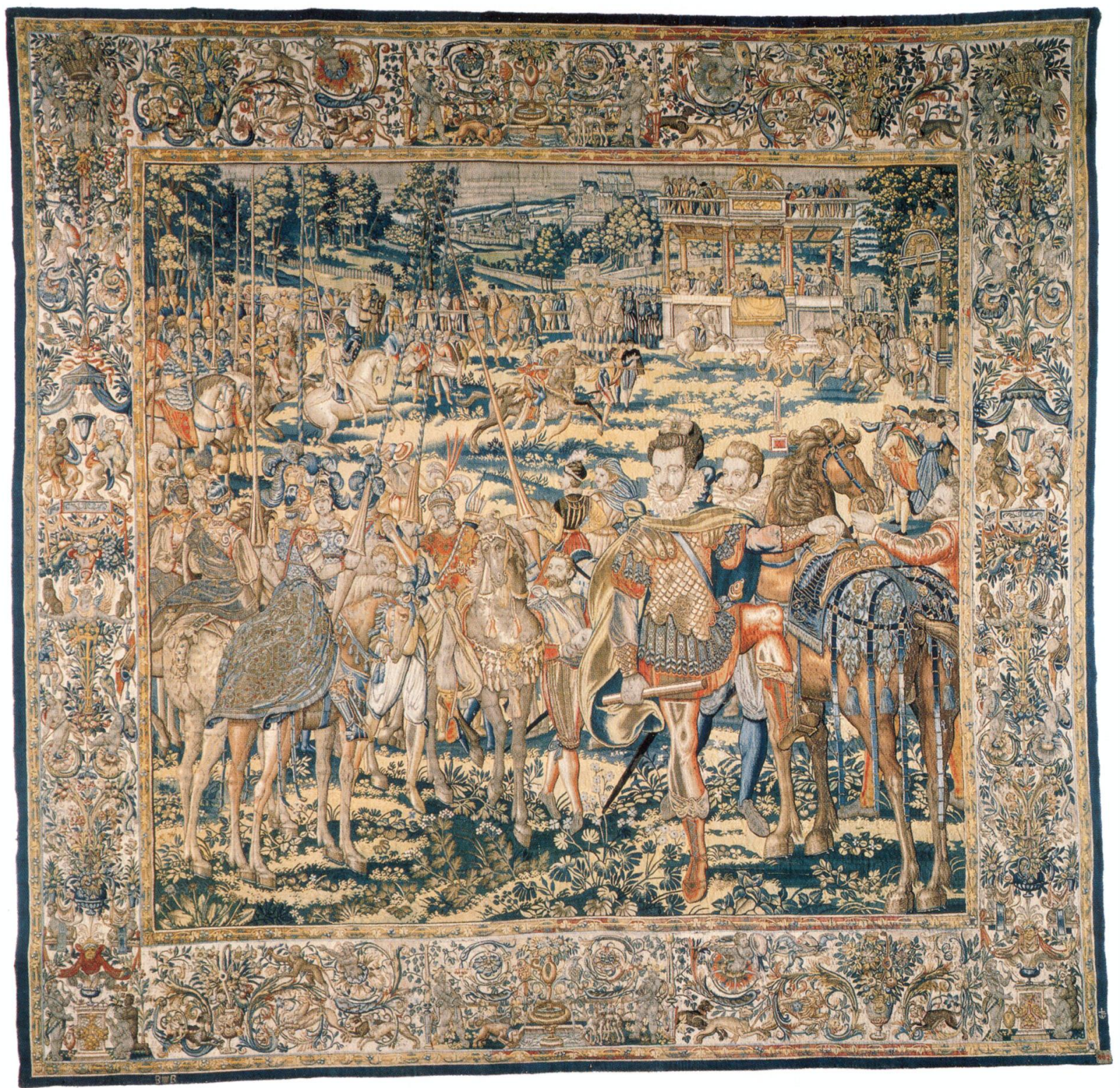

FIGURE 2

Jeu de la quintaine (Quintain). Brussels tapestry, unidentified atelier, c. 1575. Wool, silk, gold, and silver, $387 \times 400 \mathrm{~cm}$. Photo: Casa Editrice Sillabe, Livorno. queen mother, who had no equal other than "her great uncle Pope Leo and Lord Lorenzo the Magnificent," according to Pierre de Bourdeilles de Brantôme. ${ }^{10}$ Three of these scenes evoke the festivities at Bayonne in 1565, marking the end of the grand tour of France taken by Catherine and her young son Charles IX, after their meeting with her older 
daughter Élisabeth (1546-1568), wife of Philip II of Spain. A fourth episode recalls a nautical party given at Fontainebleau, just before the departure in 1564 for the above-mentioned tour of France. The fifth scene, Fête aux Tuileries en l'honneur des ambassadeurs polonais (Polish Ambassadors) (Fig. 7), depicts the reception of the Polish ambassadors who came to the Tuileries in 1573 to elect Catherine's second son, Henri d'Anjou, to the Polish throne. In this garden, "festivals, jousts, foot and horse combats" were given, as well as a court ballet, "the most beautiful ballet that was ever produced in the world," according to Brantôme, where one could see Apollo on a rock, an allusion to Henri, and sixteen nymphs symbolizing the French provinces. ${ }^{11}$ A sixth festivity was the Combat à la barrière (Fig. 6), a frequent performance that could have been given at Fontainebleau in 1564 , but also elsewhere. ${ }^{12}$ It should be recalled that Henri II died on July 10,1559, following a wound received during a joust that pitted him against Gabriel de Montgomery, the captain of his Scottish guards, on the occasion of a tournament organized for June 30 to mark the wedding by proxy of Élisabeth with Philip II of Spain on June 22. A seventh scene, Mascarade à l'éléphant (Fig. 5), shows an extravagant masquerade, with an automated elephant under attack. There had been such a festival when François-Hercule d'Alençond'Anjou entered Antwerp in 1582, which allowed Yates to deduce that the tapestries were produced for that event, as no mention of a similar performance is known in the accounts of royal parties. This type of masquerade could have been given on other occasions, however, if the association is made to a painting in the style of Antoine Caron (c. 1520-c. 1579); collection Jean Ehrmann) apparently done around $1600 .{ }^{13}$ Finally, an eighth scene, Départ de la Cour du château d'Anet (Journey) (Fig. 8), represents the royal retinue in procession before the Château d'Anet, where Queen Catherine is shown in a litter (an episode that according to Yates is an allusion to the journey of the duc d'Anjou to his new kingdom, Poland), and the young King Charles IX (d. 1574) rides at the head of the line (center foreground, facing out). Charles IX has the features of his brother Édouard-Alexandre, duc d'Anjou, ${ }^{14}$ who in 1574 succeeded him as Henri III. ${ }^{15}$

The commonly used title of each of these pieces has been determined by the festivity represented (Yates's organization of the tapestries in the series only partly follows the chronological order of the events depicted), and that title completely ignores the figures standing in the foreground. ${ }^{16}$ The primacy accorded to the festivals in the title of each tapestry has oriented the reading of the compositions, which have generally been understood as historiated scenes, framed by life-sized 


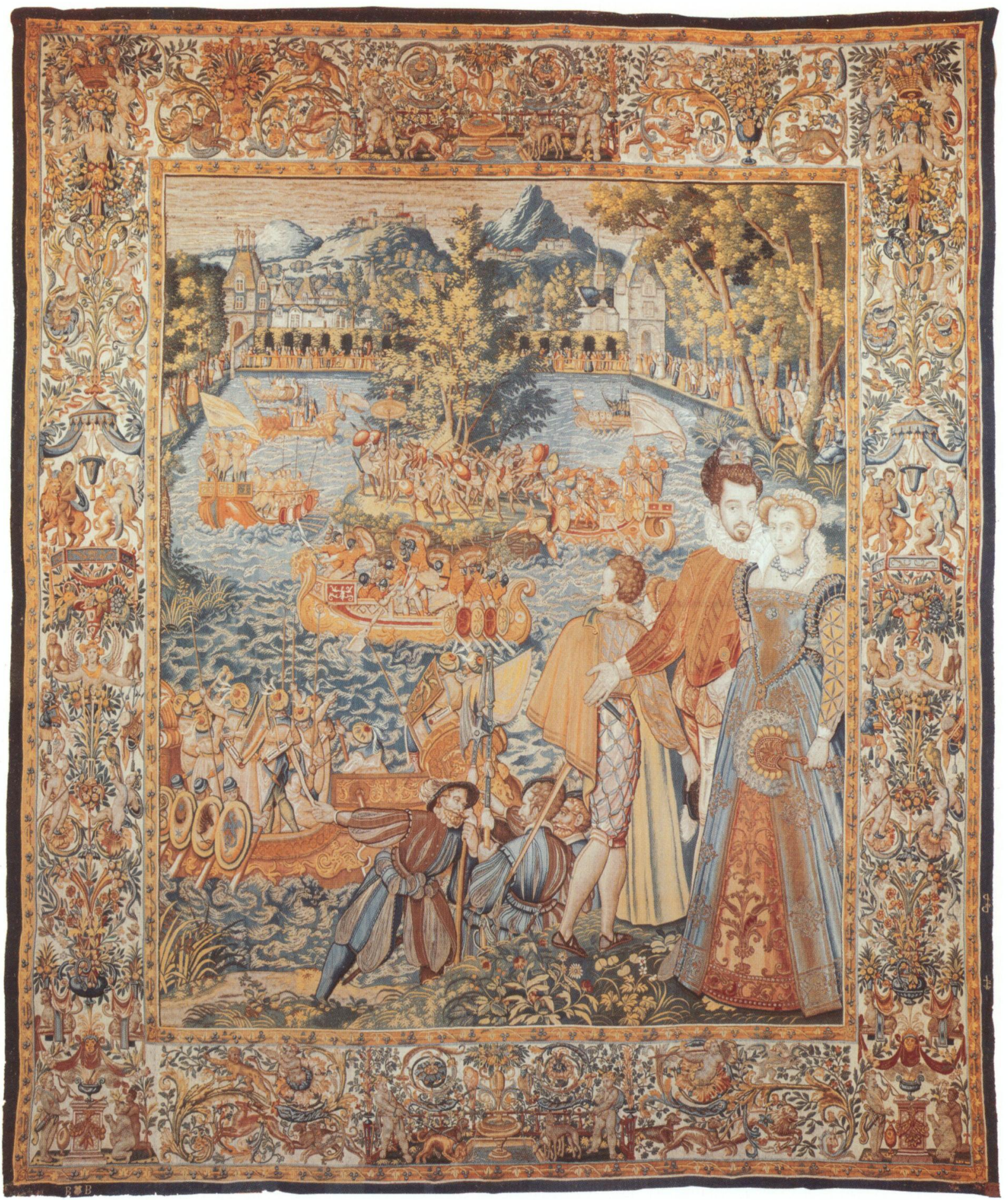


portraits serving as mere repoussoirs, arranged in one or the other of the two lower corners of each tapestry (Fig. 1). Only Strong speaks first of the portraits, which are placed laterally in the foregrounds on terraces overlooking each historiated scene, therefore appearing to be superimposed on the scene itself. Neither he, nor anyone else, however, made a connection between the foreground and background compositions.

These two types of approaches to the meaning of the series do not go any further than the mere observation of a simple relationship between the background scene and the figures in the foreground, and thus miss the deeper meaning of the tapestries. They offer no definition of the relationship between the two levels of the image, which function as two juxtaposed spaces, held together by the surface of the tapestry itself. The "portrait space" is constituted by the illustrious members of the court, represented life-size, standing in the foreground in a clearly defined space, a terrace sometimes made concrete by the inclusion of a railing or marble steps (Fig. 7) ${ }^{17}$ Gathered into small groups (from two to four people), the members of the royal family are at once the attentive spectators of the festivities enacted in the background and the viewer's "presenters" to the entertainments shown. The events figuring in the backgrounds constitute what can be called the "space of the historiated scene." This space is generally closed at the front by the figures who stand, sit, or are shown half-length, watching the spectacle. They sometimes comment on it or even direct their gaze toward the viewers and invite them to admire the party, playing therefore the role of the Albertian "admonisher." ${ }^{18}$ A distancing is at work, which results from the difference in scale of the figures belonging to one or the other of the spaces: those of the "portrait space" are of course larger than those of the "space of the historiated scenes" (Fig. 4).

The viewer is thus doubly implicated in the tapestries. The technique of taking the spectator aside is used to emphasize the interaction between the scenes. In these tapestries, viewers see their "doubles," both in the figures of the "portrait space" and in the spectators of the "space of the historiated scenes." This complex representational game evokes the "inverted still-life paintings" in Antwerp art of the 1550s, in which a still life in the foreground bears an ambiguous relationship to a religious scene in the background. ${ }^{19}$ Whatever the direction of the reading-from the "portrait space" to that of the "space of the historiated scene" or vice-versa-the tapestries put a similar device into play, with a message that can be understood as worthy of the royal family.
FIGURE 3 (facing page) Attaque de l'île devant le château de Fontainebleau (Fontainebleau). Brussels tapestry, unidentified atelier, c. 1575. Wool, silk, gold, and silver, $404 \times 344 \mathrm{~cm}$. Photo: Scala/Art Resource, New York. 


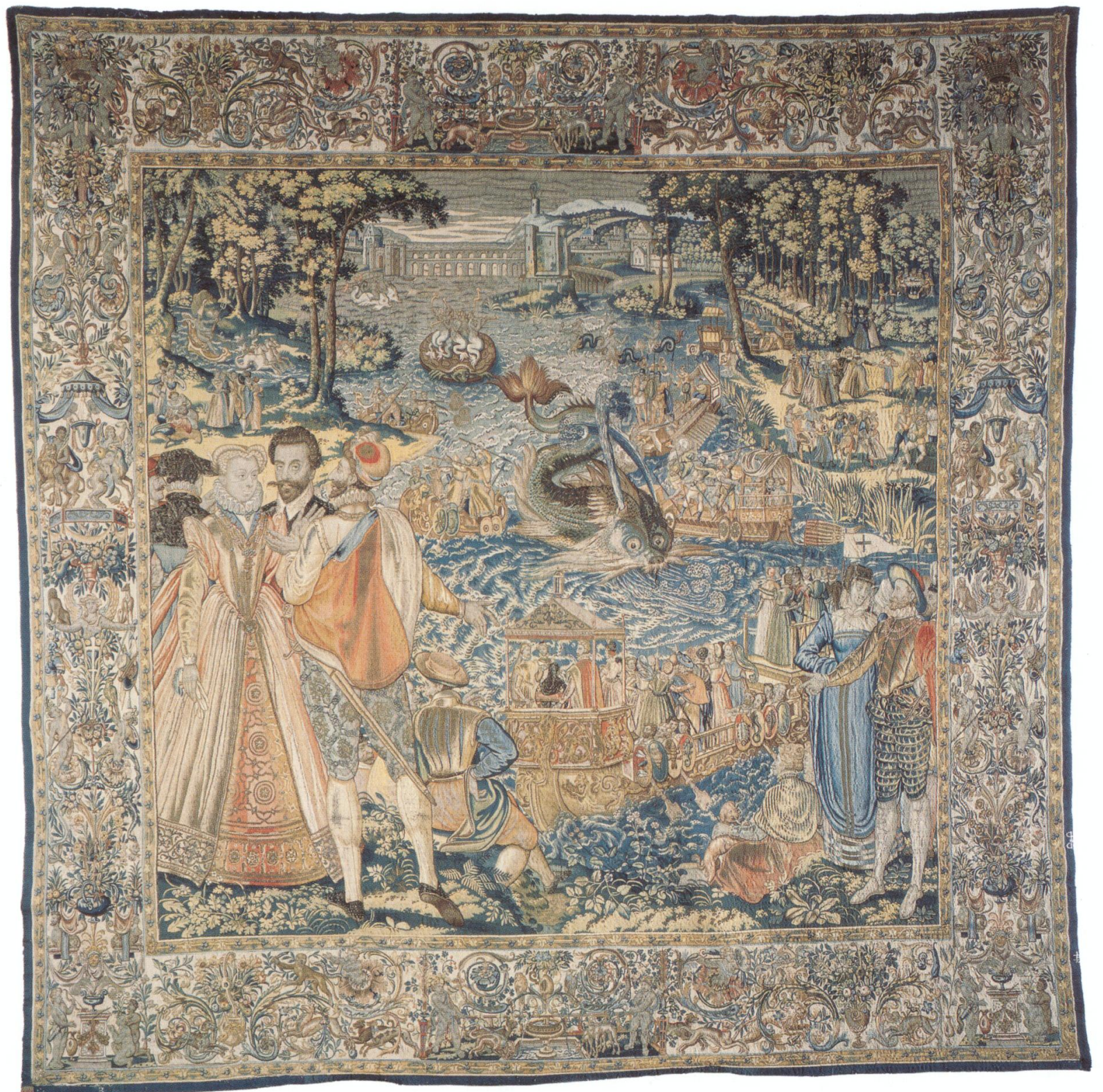

FIGURE 4

Fête nautique sur l'Adour (Whale). Brussels tapestry, unidentified atelier, c. 1575.

Wool, silk, gold, and silver, 355 x $394 \mathrm{~cm}$. Photo: Casa Editrice Sillabe, Livorno.

\section{A Double Allegorized Image of the Valois}

The originality of the Valois hangings lies in their playful combinations, of famous people in the foreground, who link the series to woven ensembles of princely portraits intended as dynastic praise and as legitimizing the monarch or the reigning family, ${ }^{20}$ and of princely festivals in the background that have a political function or symbolic value. ${ }^{21}$ The 
gold used in the weaving makes the cloth product itself precious, and dignifies what is represented. The gold supports de Groër's idea that the tapestries were a commission from royalty or from the entourage of the queen mother. It is the association of these factors that permits a new reading of the series, which can be seen as a picture (not to say a portrait) of Catherine de Médicis in 1575-1576, a difficult period in her life.

The queen mother was strongly affected by the death of her daughter Claude de Lorraine several days before the wedding of Henri III, and she did not find any comfort in her surviving children who lived with her at court, or in the king, the duc d'Alençon, her daughter Marguerite de Valois, or her son-in-law Henri de Navarre. She had to contend with their conflicts, which had stirred up rebellion in a climate of national malaise. Slanderous tracts about Catherine, such as the Discours merveilleux de la vie, actions et déportements de la reine (appearing in the summer of 1574), and the Reveille-matin des Français et de leurs voisins composé par Eusèbe Philadelphe (1574; written in February 1573), denounced the queen mother as primarily responsible for the country's woes, censured her actions, and condemned her private life. The tracts went so far as to demand the replacement of the Valois monarchy, making a direct appeal to the Guise family, and calling for the execution of Catherine. ${ }^{22}$ Henri III criticized his sister for her libertinage- her real or supposed lovers. He also had his brother d'Alençon, whom the king's minions enjoyed insulting without being reprimanded, placed under surveillance. In vengeance, the queen mother's daughter Marguerite had no trouble making allies of her husband and her brother. The result is known: d'Alençon fled to his properties in western France in September 1575; de Navarre withdrew to his holdings in the southwest in early 1576 and converted to Protestantism; and Marguerite was imprisoned (and only freed on the intervention of her mother). The queen mother continued to negotiate with the Protestants to sign the treaty of Beaulieu-lès-Loches, also called the paix de Monsieur (May 7, 1576). The king made large concessions to the Protestants, and his brother d'Alençon saw the largest profits, receiving enormous additional privileges from the Crown and taking the title of the duc d'Anjou. ${ }^{23}$

Catherine de Médicis was the inspiration for national reconciliation and unity that drove the peace edict of 1576 , and she can be seen as using the tapestry series to political ends. It presented a dignified image of the royal family, thereby glossing over the family discord and the rumors that caused it, placing Catherine with her children at her side next to the festivals of the previous reign, which symbolically recalled the moral principles in which the queen mother believed. Care was taken not to 
represent the king in the company of his brother and his sister, while Marguerite is shown with her brother François-Hercule, duc d'Alençon.

In Figure 1, Catherine de Médicis appears in the company of her daughter Marguerite and her son-in-law Henri de Navarre, across from the spouse of the king, Louise de Vaudémont, a princess without a fortune and without a hope of succession, ${ }^{24}$ apparently surrounded by her own relatives (the Guises, of whom she was a distant cousin), observing a performance of the Carrousel des chevaliers bretons et irlandais à Bayonne. This court ballet, which was held in Bayonne on June 25, 1565, involved a simulated battle of knights on horseback, the one side representing Virtue and the other, Love. In the background appear, to the right, the chariot of the Cardinal Virtues, in which Prudence, Valor (or Strength), Justice, and Temperance have all taken their places, and, to the left, the chariot of Love carrying Venus and Cupid, surrounded by a cortege of putti as indicated by the Recueil des choses notables qui ont été faites à Bayonne (Paris, 1566). The message is clear. It recalls the Valois alliances concluded through marriages with the Bourbons and the Guises, as well as the principal virtues that Catherine's daughters had to possess.

In Figure 2, the image of Henri III associated with the Jeu de la quintaine evokes the skill and the valor of the king, represented as an ideal prince, in the costume of the imperator, holding the commander's baton in his right hand. This image is strengthened by the representation of costumed knights who, during the Bayonne festivals on June 19, had participated in the jeu de bagues, played on horseback with galloping riders trying to run a lance through a suspended ring. The Recueil des choses notables qui ont été faites à Bayonne describes the king, Charles IX, as the Roman Emperor Trajan, his brother Henri following him disguised as an Amazon and the "chevaliers Maure, Espagnol, Romain, Grec, et Albanais, accompagnés de dames de leur pays" and other lords disguised as "femmes à l'antique" with masked faces (see, for example, the small male figure in the background scene holding a mask in his right hand, just behind the large figure of Henri III in the left center foreground). ${ }^{25}$ Henri III also appears, accompanied by his wife, in the tapestry of the Attaque de l'île devant le chateau de Fontainebleau (Fig. 3), a spectacle that included the freeing of women imprisoned on an enchanted island by the king and his brothers. The meaning seems evident: the Monarchy liberates its obedient subjects.

Marguerite de Valois is represented, as has been seen, with her mother. She also appears with her husband de Navarre and her brother d'Alençon. The Fête nautique sur l'Adour (Fig. 4), where Marguerite and de Navarre are shown with Charles de Lorraine, recalls the sumptuous 
banquet given by Catherine de Médicis on June 24, 1565, in a "large octagonal room," set up on the island of Adour, surrounded by trees "where the queen my mother," wrote Marguerite in her memoirs, "arranged small niches all around, and in each one a round table for twelve people." 26 During the crossing of the guests to the island, a water and music spectacle was given, during which an attack on an artificial whale took place. The theme was peace between France and Spain, with universal peace represented by the gods of nature (Neptune, Tritons, sirens) around the king of France, following the defeat of the monster of war (the whale). On the banks, shepherds (an allusion to the French provinces) danced to the sound of the French horn. ${ }^{27}$ Finally, after dinner, a ballet of nymphs took place. Here again the symbolism is clear: the celebration of universal peace and the commemoration of the festivals, including the "Paradis d'Amour," held in honor of Marguerite de Valois's wedding to Henri de Navarre (1572). (This was the infamous "vermillion wedding," still in everyone's memory, red with the blood of the St. Bartholomew's Day Massacre.) ${ }^{28}$ Mascarade à l'éléphant (Fig. 5), a kind of military ballet around a representation of an elephant, symbol of the royal person, evokes the traditional notion of force, strength, and power. ${ }^{29}$ The tapestry is a representation of the three living children of Catherine de Médicis, King Henri III (symbolized by the ballet's elephant), with Marguerite de Valois and François-Hercule d'Alençon, standing in the foreground to the right. ${ }^{30}$ D'Alençon is also represented in the foreground of the Combat à la barrière (Fig. 6), a frequent joust in tournaments and festivals, which emphasized the courage and valor of the armed knights fighting with long spears. After the St. Bartholomew's Day Massacre, d'Alençon was advanced by the queen mother and the king in the hopes of bringing peace back to the kingdom. ${ }^{31}$

The last two tapestries no longer show the queen mother and her children, but people of uncertain or at least debated identity, who must have been close to the Crown, the favorites of the king. Scholars have recognized Henri de Guise or Anne de Joyeuse in the foreground of the Fête au Tuileries en l'honneur des ambassadeurs polonais (Fig. 7). Henri de Guise belonged to the private Council and under Charles IX and Henri III was grand master or "first servant" to these kings, until he opposed the king in 1578 and was distanced from royal affairs in 1585. Anne de Joyeuse, one of the principal favorites of Henri III, was raised to the title of duke in 1581, the year in which he married Marguerite de Lorraine, the king's half-sister. Wouldn't it be better to seek the identity of the three figures represented in the right foreground of the Départ de la cour $d u$ château d'Anet (Fig. 8) among the companions of the trip to Poland 


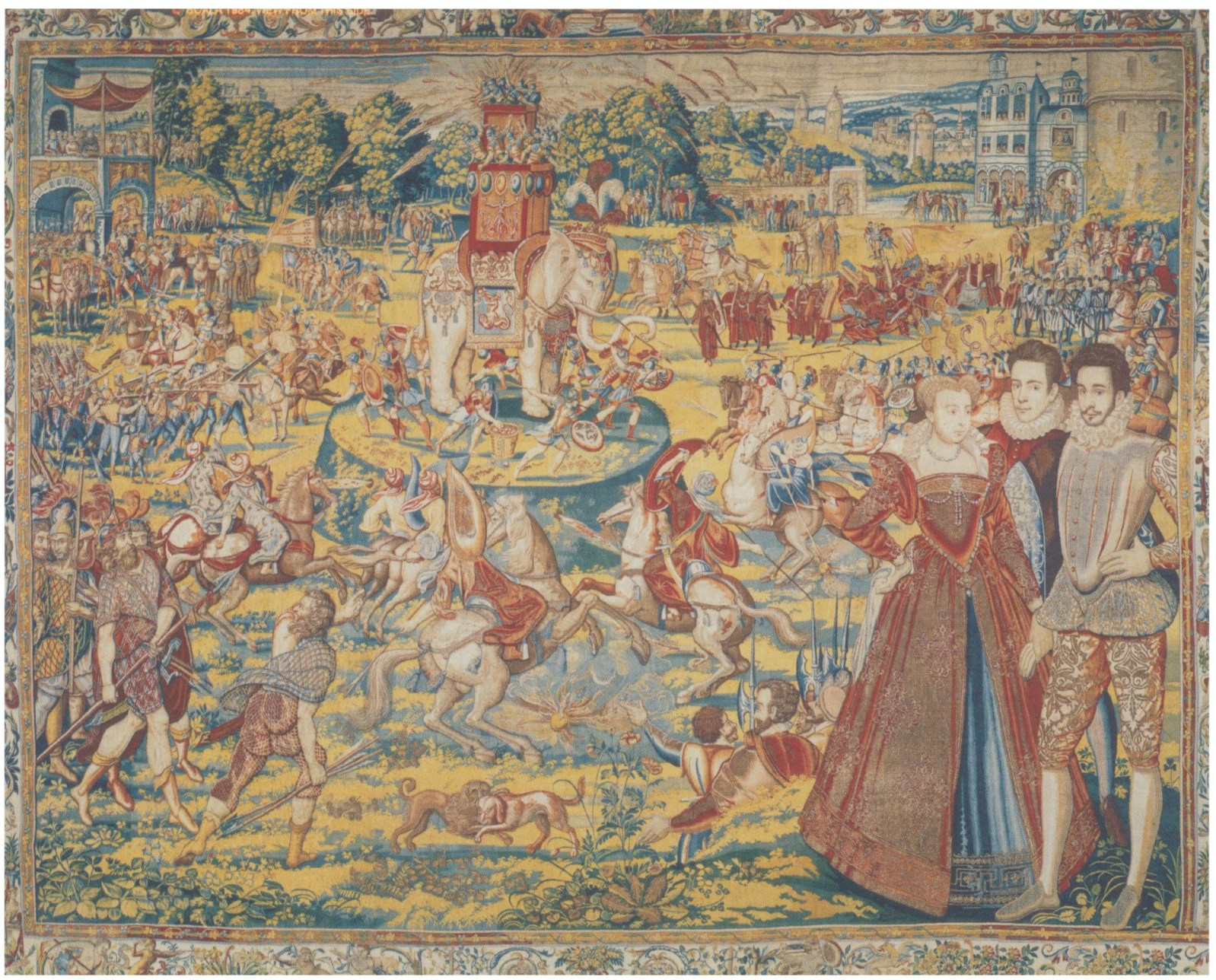

FIGURE 5

Mascarade à l'éléphant (Elephant). Brussels tapestry, unidentified atelier, c. 1575.

Wool, silk, gold, and silver, $387 \times 670 \mathrm{~cm}$. Photo: Scala/Art Resource, New York.

FIGURE 6 (facing page)

Combat à la barrière (Barriers). Brussels tapestry, unidentified atelier, c. 1575.

Wool, silk, gold, and silver, 386 × $328 \mathrm{~cm}$.

Photo: Casa Editrice Sillabe, Livorno.
(Pibrac, the maréchal de Bellegarde, Larchant, Villequier, and so forth) and the king's favorites (the duc d'Épernon, the comte de Quélus, d'Entragues, Bussy d'Amboise, and so forth), since the royal retinue is shown in the background? It is the case, however, that the identification of undocumented portraits remains one of the most delicate tasks to carry out. $^{32}$

These examples should suffice to show that the Valois tapestries can no longer be viewed, as Yates thought, as representing a celebration of the arrival of d'Alençon-d'Anjou in Holland. They are instead a veritable Histoire de Catherine de Médicis or a Histoire des derniers Valois. The queen mother appears in the weavings, as she appeared in the triumphal entries into towns, surrounded by the royal family, by her children whom she molded in her own image. Indeed, she imbued them with Neo- 


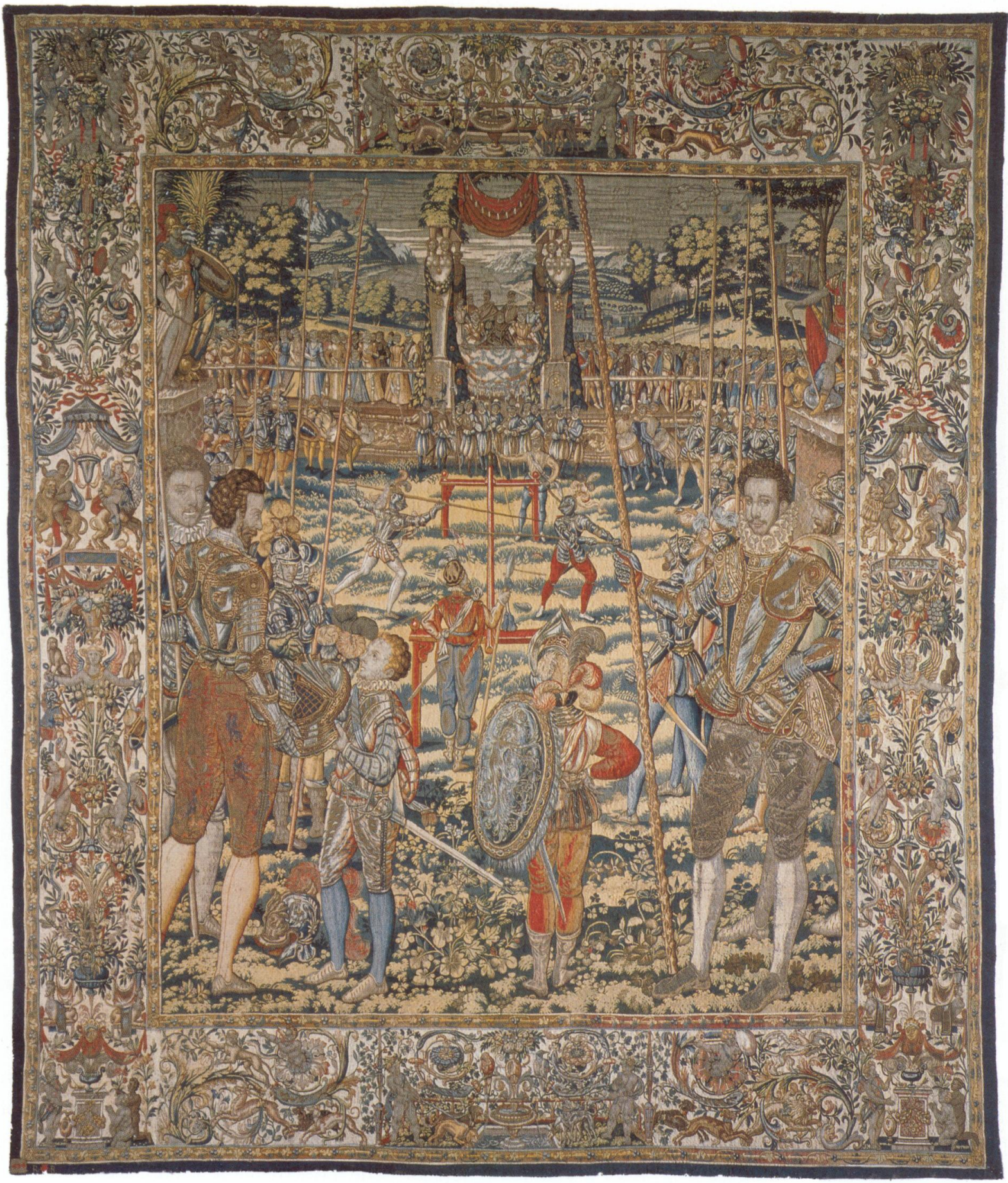




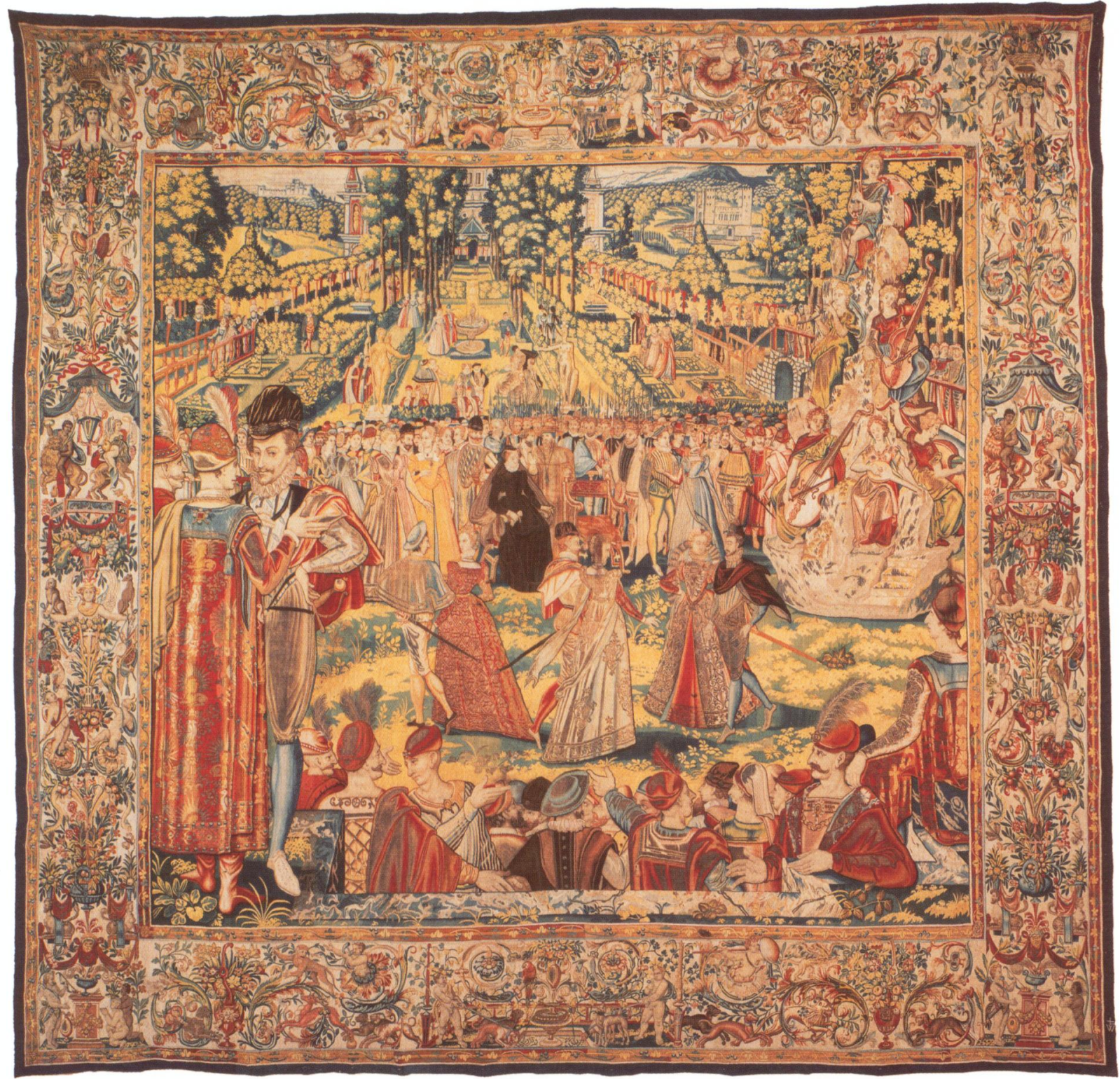

FIGURE 7

Fête aux Tuileries en l'honneur des ambassadeurs polonais (Polish Ambassadors). Brussels tapestry, unidentified atelier, c. 1575 . Wool, silk, gold, and silver, 388 x 480 cm. Photo: Scala/Art Resource, New York.
Platonic values and taught the princes how to hold court. ${ }^{33}$ Under the guise of representing festivals from the previous reign, the queen mother made clear that she still held the reins of power during the 1575-1576 truce in the wars of religion. The series therefore offers a double image of Catherine de Médicis and her family: the first, demonstrating the supernatural and atemporal nature of the Valois dynasty; the second, showing the harmony, concord, and peace that the queen mother sought her 
entire life (though vainly), believing as she did in the merits of the peace edicts. These would include the Peace of Amboise (1563), the Peace of St. Germain (1570) after the second and third wars of religion in France (1567-1568), and the Peace of Beaulieu (1576).

\section{Quickly Executed Tapestries}

It is appropriate to make two additional observations to support the rereading proposed here. The first, of a technical order, concerns the conditions of weaving and the place of execution. If the series was a royal commission, it could be asked why it was made in Brussels, given that Paris had ateliers founded by Henri II in the middle of the century. Nevertheless, Parisian weaving activity was modest and slower in delivery than in Flanders, which had a larger work force. The monarchy's need quickly to produce a forceful image of the Crown required a rapid production that the Brussels workshops were much better equipped to assume. $^{34}$

The second point is that the weaving of the Valois tapestries may explain why the series called the Histoire d'Artémise, planned earlier (in 1562), was only executed much later (beginning in 1600). This series was based on a poem by the Parisian philanthropist and apothecary Nicolas Houel, who wrote that its purpose was the glorification of Catherine de Médicis educating her son, the future Charles IX, following the example of the ancient queen Artemisia, widow of King Mausolus (ruler of Caria, d. 353 B.C.; modern southwestern Turkey), who reared her son Lygdamis. ${ }^{35}$ This series was not woven before the Valois tapestries, however, because there was no reason to: the Valois tapestries provided a clear image of the queen mother and her family in place of the veiled allegory of Catherine de Médicis proposed in the Histoire d'Artémise. ${ }^{36}$

It should be pointed out, however, that these two series of tapestries were executed twenty-five years apart, but from drawings by the painter Antoine Caron, who made all at the same time. It was also during this period that Caron drew the illustrations for the Histoire française de notre temps, commonly called the Histoire des rois de France, another poem by Houel intended to glorify Catherine de Médicis. ${ }^{37}$ The drawings of the Histoire d'Artémise (Fig. 9) were specifically executed to serve as models for tapestries, ${ }^{38}$ and so, it seems, were those for the Histoire des rois de France (which were never woven). The drawings linked to the Valois tapestries represent only the festivals, however, and do not carry borders, whereas the other two sets of drawings have extremely elaborate borders. The Valois tapestry drawings could perhaps be the first thoughts for a 


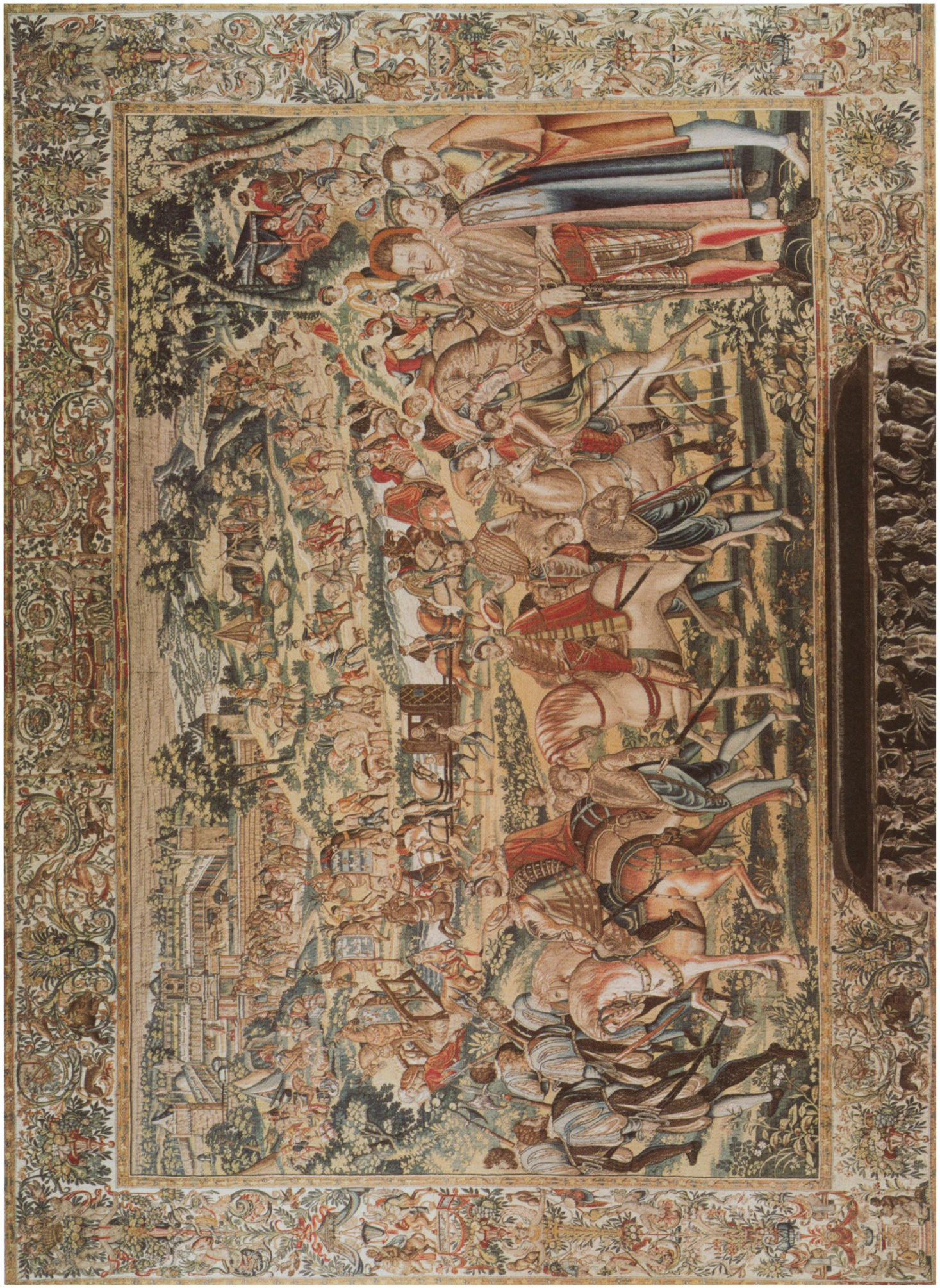




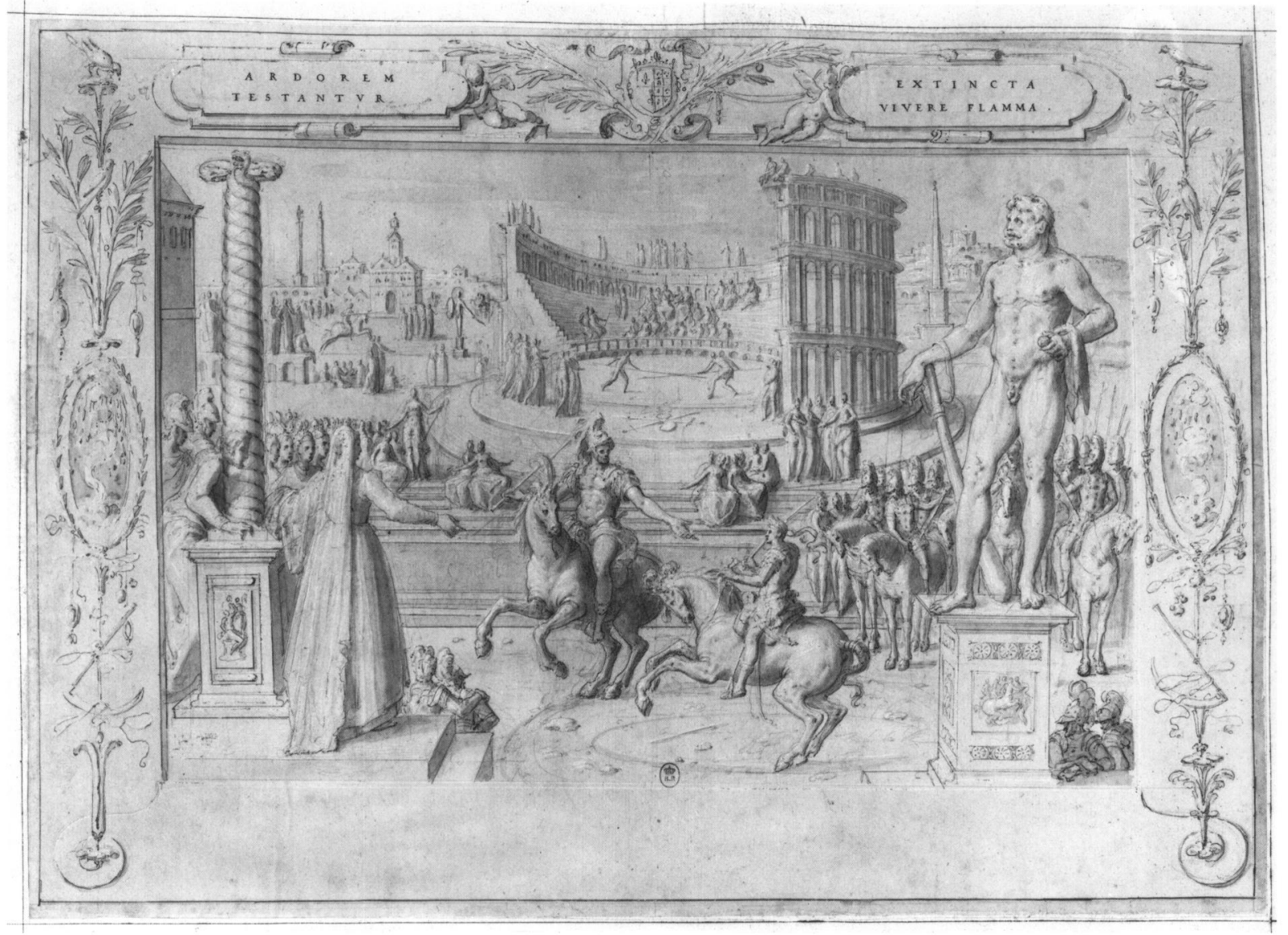

woven cycle or for a completely different project (Fig. 10). ${ }^{39}$ No study drawings for the portraits have been found. Could Caron, who was an important portraitist, have also been the author of the portraits in the Valois tapestries? This question leads to the reconsideration of the attribution of the cartoons that Yates suggested should be given to the Flemish painter Lucas de Heere (1534-1584). The English historian based her hypothesis on the fact that the Flemish painter was a confirmed cartoon maker and a portrait and costume specialist, that he had known Catherine de Médicis (around 1560), and that, in the service of William of Orange, he had worked for the glory of d'Alençon-d'Anjou in giving the drawings for the festivities around the entry of this prince to Antwerp. ${ }^{40}$ The argument is weak and, as if trying to reinforce it, Yates added that she thought she recognized the emblem of Lucas de Heere in two tapestries (a siren playing a lyre with a sailor hanging from her tail that the painter used in libri amicorum). This motif can be clearly recognized,
FIGURE 8 (facing page)

Départ de la Cour du château d'Anet (Journey). Brussels tapestry, unidentified atelier, c. 1575. Wool, silk, gold, and silver, 390 x $534 \mathrm{~cm}$. Photo: Scala/Art Resource, New York.

\section{FIGURE 9}

Antoine Caron, Équitation, Paris, 1562 1571. Brown ink, brown wash, white heightening, and black chalk on paper, 39.7 x $55.4 \mathrm{~cm}$. Bibliothèque Nationale de France, Paris. 


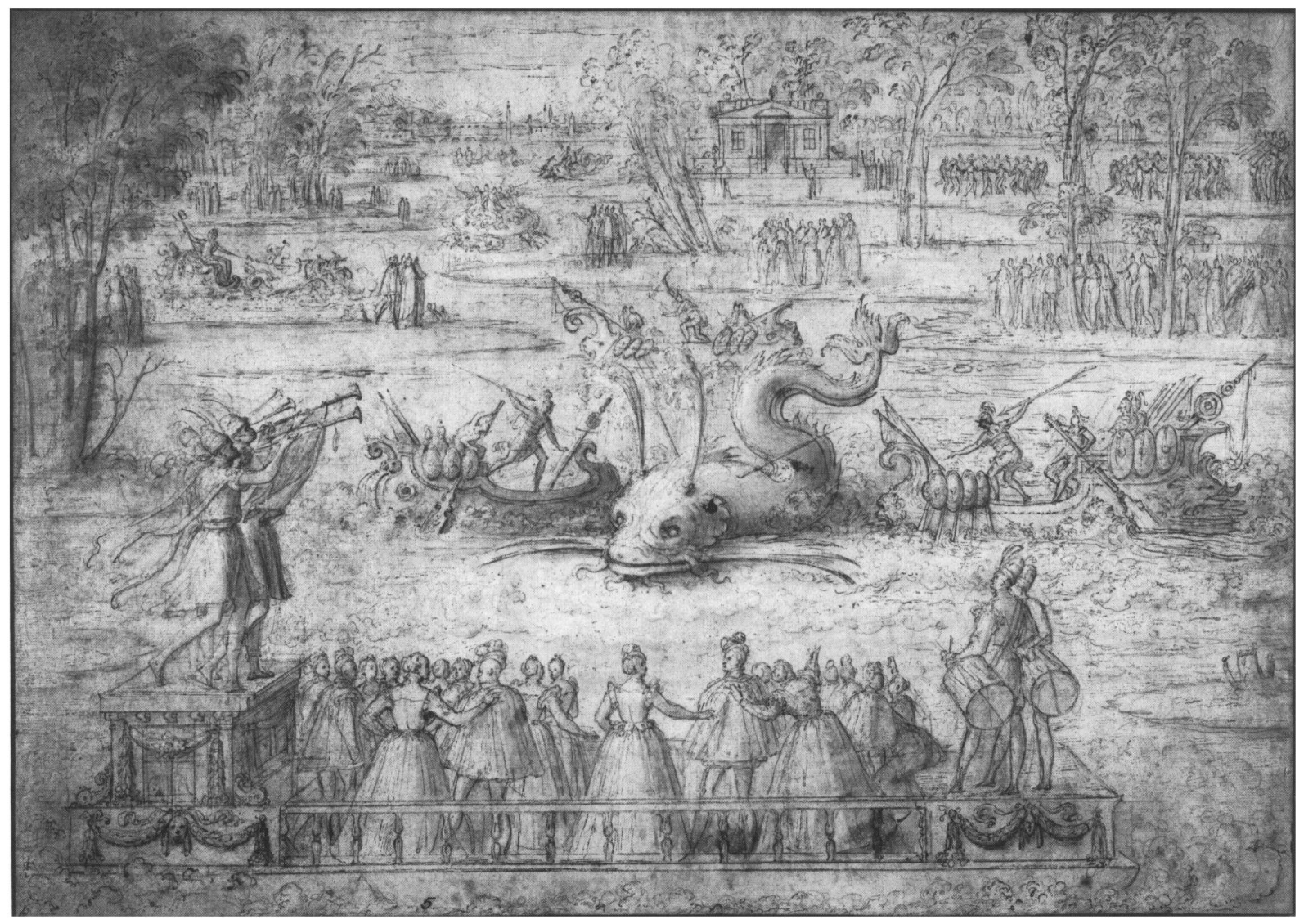

FIGURE 10

Antoine Caron, The Water Festival at Bayonne, June 24, 1565 (Whale), Paris, 1570-1574. Black and brown ink, and some black ink, gray-brown wash, white heightening, on paper, $34.9 \times 49.3 \mathrm{~cm}$. Pierpont Morgan Library, Dept. of Drawings and Prints, New York. but is it really the painter's emblem? The complicated question of attribution goes beyond the scope of this paper, which is focused on the meaning of the Valois tapestries, but it seems necessary at least to raise it, even if for the moment another name is not proposed. In any case, it would be better to return the work to an anonymous author rather than to persist in a highly debatable attribution.

In conclusion, the queen mother's shipment of the set of tapestries to Florence did not occasion a slippage of its meaning, notwithstanding Yates's argument. ${ }^{41}$ In offering the series to her granddaughter Christine de Lorraine, Catherine de Médicis must have wanted to remind her one last time of the values that she, Christine, had been taught at the French court after the death of her mother, Claude. In the scenes, the young grand duchess could view a commemoration of the history of her grandmother. ${ }^{42}$ Moreover, the hangings from France lost none of their grandeur next to the best pieces of the Medici collection, such as the luxurious suite from Brussels of the Histoire de la Création de l'Homme 
(traditionally attributed to Jan C. Vermeyen) or the famous Histoire de Joseph designed by Jacopo Pontormo, Francesco Salviati, and Agnolo Bronzino woven in Florence from 1546 to 1553 in the manufactory founded by Cosimo I de' Medici. On the contrary, the series found its rightful place amid the Florentine series glorifying the memory of the illustrious members of the Medici family, Cosimo the Elder, Lorenzo the Magnificent, and Clement VII, produced from cartoons by the Flemish Giovanni Stradano (Jan van der Straet) and designed to decorate the rooms at the Palazzo Vecchio named for these Medici family members. In offering a tapestry series telling her own history to her granddaughter, Catherine de Médicis therefore inscribed herself in the woven pantheon of Tuscany, the grand duchy that she had vainly coveted her entire life.

\section{Appendix}

The identity of the figures in the foreground of the Valois tapestries. The titles in parentheses are those used by Frances A. Yates in The Valois Tapestries (London, 1959 and 1975). (When an identification is uncertain or debated, the names of the authors of each proposition are given in parentheses.)

\section{Carrousel des chevaliers bretons et irlandais à Bayonne (Tournament) (Fig. 1)}

On the left, Catherine de Médicis in mourning, one of her dwarfs at her feet. ${ }^{43}$ Behind the queen mother, on her right, her daughter Marguerite de Valois and her husband Henri de Navarre. On the right, Louise de Vaudémont (wife of Henri III) accompanied by a man and two women, one of whom is seen from the back.

The woman seen from the back on the right has been identified as Marguerite de Lorraine-Vaudémont (half-sister of the queen Louise de Vaudémont), who married Anne d'Arques, duc de Joyeuse, in $1581 .{ }^{44}$ For the group on the right, Gertrude T. Van Ysselsteyn proposed the name of Louise de Vaudémont, her brother-in-law, Charles de Lorraine, whom she calls François by mistake, and his sister, the duchess of Bavaria. ${ }^{45}$ In the figure of the dwarf, Van Ysselsteyn also thought she recognized a child, Henri, born in 1573 to François de BourbonMontpensier and Renée d'Anjou, and then the presumed heir to the throne. ${ }^{46}$

\section{Jeu de la quintaine (Quintain) (Fig. 2)}

Henri III, in antique costume, about to mount a horse. Behind him, to the right, one of the king's favorites, whom Ivanoff believes is the duc de Joyeuse. ${ }^{47}$ 


\section{Attaque de l'île devant le château de Fontainebleau (Fontainebleau) (Fig. 3)}

On the right, Henri III and his wife, Louise de Vaudémont.

\section{Fête nautique sur l'Adour (Whale) (Fig. 4)}

On the left, Marguerite de Valois (in three-quarter view), Charles III of Lorraine (full face), and Henri de Navarre (three-quarter view from the back).

\section{Mascarade à l'éléphant (Elephant) (Fig. 5)}

On the right, Marguerite de Valois and her young brother François-Hercule, duc d'Alençon. Between them, an unidentified young man, perhaps Edmund Sheffield, the stepson and guard of the earl of Leicester, ${ }^{48}$ or the young James of Scotland, son of Mary Stuart, whose mother belonged to the Lorraine-Guise family. $^{49}$

\section{Combat à la barrière (Barriers) (Fig. 6)}

On the right, François-Hercule, the duc d'Alençon. On the left, the man in armor holding a helmet, the young squire, and the man holding a lance are unidentified. Yates thought she recognized in these three figures a group portrait of the Nassau family, with William of Orange himself as the man in armor holding a helmet and his second son, the young Maurice de Nassau. ${ }^{50}$ Van Ysselsteyn, on the other hand, identified the man in armor as Jean Casimir and the man with the lance as Guillaume-Louis de Nassau, the older son of Jean, elder brother of the Orange family, and defender of the northern provinces. ${ }^{51}$ It seems more logical to me to see them as some of the duc d'Alençon's friends.

\section{Fête aux Tuileries en l'honneur des ambassadeurs polonais (Polish Ambassadors) (Fig. 7)}

On the left, two figures, one facing out and the other seen from behind. The man facing out has been recognized as Henri, duc de Guise, responsible for the reception of the Polish ambassadors (according to Ivanoff, ${ }^{52}$ followed by Barbara A. Heezen-Stoll), ${ }^{53}$ or (according to Yates) ${ }^{54}$ Anne, duc de Joyeuse. The latter identification was rejected by Léon de Groër, ${ }^{55}$ in spite of the strong resemblance to Joyeuse, who should have, if the reference to his marriage is correct, worn the chain of the Order of the Holy Spirit.

\section{Départ de la cour du château d'Anet (Journey) (Fig. 8)}

On the right, three unidentified figures. Ivanoff stated that the man leaning on a sword was Jean-Louis Nogaret de La Valette, one of Henri III's minions, who in 1581 received the duchy of Épernon and was named colonel general of the infantry. ${ }^{56}$ Behind him Ivanoff recognized the famous chronicler Pierre de Bourdeilles de Brantôme. ${ }^{57}$ According to Yates, the man leaning on the sword is 
Ludovic de Nassau (1538-1574), one of the younger brothers of William of Orange, who had persuaded Jeanne d'Albret to consent to the marriage of her son to Marguerite de Valois. ${ }^{58}$ Yates also says that the two others are Christophe de Palatinat and Henri de Nassau. The former was with Ludovic de Nassau at the end of November 1573 at Blamont, in Lorraine, when Henri (future king of France as Henri III) left for his new kingdom in Poland. According to Van Ysselsteyn, these two men are Adolphe de Nassau (d. 1568), his brother Louis, and Philippe de Marnix de Sainte Aldegonde, Henri III's ambassador to Holland. ${ }^{59}$ These identifications were rejected by de Groër. ${ }^{60}$ Heezen-Stoll proposes to identify the man with the sword as Bussy d'Amboise, one of François-Hercule d'Alençon's men, who distinguished himself in 1577 at the siege of Maubeuge and neighboring places. ${ }^{61}$ This identification, if it could be confirmed, would have the advantage of allowing the dating of the tapestry to before 1579 , the date of the assassination of this formidable duelist, given that all of the figures with portraits in the foreground were living at the moment the tapestries were produced. In any case, the identity of these three figures should in fact be sought among Henri III's favorites, and not those of the House of Orange.

\section{NOTES}

This study began as a paper read at the symposium Les Médicis et la France, held at the château de Blois on September 25, 1999, on the occasion of the exhibition Les Trésors des Médicis. I would like to thank Thierry Crépin-Leblond, Guy Delmarcel, and Thomas Campbell for their remarks and suggestions which helped shape the final form of this article. In memoriam Françoise Bardon (1925-2005).

1. Frances Amelia Yates, The Valois Tapestries, Studies of the Warburg Institute, ed. G. Bing, vol. 23 (London, 1959). The tapestries, long held in the Uffizi, are now in the tapestry collection of the Palazzo Pitti in Florence. For an understanding of the complexities of the tumultuous family and political relations of the last members of the Valois dynasty represented in these tapestries, see, inter alia, Leonie Frieda, Catherine de Medici (London, 2003); Robert Jean Knecht, Catherine de Médicis (1518-1589), trans. Sarah Leclercq (Brussels, 2003 [1st ed., 1998]); Ivan Cloulas, Catherine de Médicis (Paris, 1979); Janine Garrisson, Catherine de Médicis: L'impossible harmonie (Paris, 2002); Pierre Chevallier, Henri III (Paris, 1985); JeanPierre Babelon, Henri IV (Paris, 1982); and Janine Garrisson, Les derniers Valois (Paris, 2001).

2. Jean Coural, L'École de Fontainebleau, exh. cat. (Paris: Grand-Palais, 1972), cat. 462. Roy Strong, Les Fêtes de la Renaissance (1450-1650): Art et pouvoir, trans. B. Coquio (first pub. as Splendour at Court: Renaissance Spectacle and Illusion [London,
1973], rev. as Art and Power: Renaissance Festivals, 1450-1650 [London, 1984]) (Le Méjan, France, 1991), 186-90. Léon de Groër, "Les tapisseries des Valois du Musée des Offices à Florence," in Hommage à Hubert Landais: Art, objets d'art, collections (Paris, 1989), 125-34. To these critiques should be added the doubts recently expressed by Robert Jean Knecht in Catherine de Médicis (1518-1589), trans. Sarah Leclercq (Brussels, 2003 [1st ed., 1998]), 281-83; and also those of Lisa Jardine and Jerry Brotton, Global Interests: Renaissance Art between East and West (London, 2000), 122-31.

3. It is true that counterfeits were produced in Antwerp. Weavers from that city purposely used the Brussels mark to fool clients. The weaver François Spiering, famous for having directed a workshop in Delft, formerly had a workshop in Antwerp, called "à l'écusson de Bruxelles," a badge that he used in his products. By associating it with his monogram, he introduced doubts as to the place of execution of the tapestries; see Guy Delmarcel, La Tapisserie flamande du XVe au XVIIle siècle (Paris, 1999), 178. The former curator of the Royal Museums of Brussels, Marthe Crick-Kuntziger, therefore supposed that Spiering could have been the producer of the Valois tapestries, which Yates recalled (Yates, The Valois Tapestries, 41-43), but Yates proposed instead that the tapestries had been executed by Josse van Herzeele and François Sweerts, because these weavers had received a payment in 1582 for the 
delivery of two rooms of tapestries destined for d'Alençon-d'Anjou at Middelbourg. Van Herzeele was a weaver of Brussels who lived in Antwerp between 1580 and 1586, when he emigrated to Hamburg, where he died in 1589. His monogram (and that of Sweerts) is different from those seen on the Valois tapestries; see Delmarcel, La tapisserie flamande, 177-78, 366. Yates's hypothesis has been long-lived: for instance, it was taken up again by Giovanna Damiani in Trésors des Médicis, exh. cat. (Munich: Kunsthalle der Hypo-Kulturstiftung, 1998), cat. 25. Coural's opinion was, on the other hand, supported by Roy Strong, then by Jean Ehrmann, Antoine Caron: Peintre des fêtes et des massacres (Paris, 1986), 190; Léon de Groër, "Les tapisseries des Valois," 128; Amaury Lefébure, "Le XVIe siècle: Une inspiration européene," in Histoire de la Tapisserie en Europe du Moyen Âge à nos jours, ed. Fabienne Joubert, Amaury Lefébure; Pascal-François Bertrand (Paris, 1995), 83-84, 128, 132; and most recently by Delmarcel, La tapisserie flamande, 127, 139; and lastly by Lucia Meoni in a catalogue entry in Gli arazzi dei Granduchi: Un patrimonio da non dimenticare, exh. cat. (Florence: Galleria degli Uffizi, 2006), cat. 4.

4. Balthazar de Beaujoyeulx and Nicolas Filleul, Ballet comique de la reine . . ., Paris, by Adrien Le Roy, Robert Ballard, and Mamert Patisson, 1582; published by Paul Lacroix, Ballets et mascarades de cour de Henri III à Louis XIV, 1516-1582 (Geneva, 1868-1870; repr. Geneva, 1988).

5. De Groër is referring to drawing no. 536 of the Cabinet des Estampes of the Bibliothèque Nationale, Paris, according to the numbering established by Jean Adhémar and Christine Moulin, "Les portraits dessinés du XVIe siècle au Cabinet des Estampes," Gazette des Beaux-Arts 82 (September 1973): 121-98, and idem (December 1973): 327 . 50

6. De Groër's conclusions were timidly repeated by Wolfgang Brassat (Tapisserien und Politik: Funktionen, Kontexte und Rezeption eines repräsentativen Mediums [Berlin, 1992], 106, 210-12, cat. 49), who mentions them without full support. Lucia Meoni ignores them in the first volume of her monumental study on tapestries in Florentine museums ( $\mathrm{Gli}$ Arazzi nei musei fiorentini. La collezione medicea. Catalogo completo, vol. 1, La manifattura da Cosimo I a Cosimo Il [1545-1621] [Livorno, 1998], 95-96).

7. The set of tapestries à figure, et fregio à grottesche et altro appears in an inventory of furniture brought from France by Christine de Lorraine to Florence. Their dimensions were $61 / 2$ "braccie" tall by 60 wide, or about $3.80 \mathrm{~m}$ by $35 \mathrm{~m}$ ( 1 braccia $=0.584$ $\mathrm{m})$, which corresponds to the dimensions of the tapestries in Florence: the average height is about $3.80 \mathrm{~m}$ and the width is about $36 \mathrm{~m}$. See Jean Ehrmann, "Dessins d'Antoine Caron," Bulletin de la Société de l'Histoire de l'Art Français (1956): 122-25 (Ehrmann indicates that he owed this discovery to Cecilia Lisi). The objects cited in this inventory (of which three versions exist; see Yates, The Valois Tapestries, $142 \mathrm{nn} .4$ and 6) are said to have been given by Catherine de Médicis during her lifetime, which means before January 5, 1589, to her granddaughter Christine de Lorraine, whom she had reared after the death in 1575 of the girl's mother, Claude de Valois. They are carefully distinguished from other objects, inventoried separately, and left as a bequest to Christine de Lorraine by Catherine de Médicis (there are no tapestries among these last objects). Jean Ehrmann and Cecilia Lisi deduced that the gift of objects noted in the first list was made at the conclusion of the marriage contract negotiations between Christine de Lorraine and Ferdinand I of Tuscany, in October-December 1588 at Blois (the contract was signed on December 8 ).

8. In 1904, the tapestries were called the Fettes d'Henri III (Henri Bouchot, Exposition des Primitifs français, exh. cat. [Paris 1904], nos. 280-81). The title "Valois tapestries" was given by Jean Ehrmann in "Dessins d'Antoine Caron." On the question of the titles of the hangings, see Ehrmann, Antoine Caron, 189.

9. On the various identifications, see Appendix. To the studies already cited, two others should be added that concentrate on the identification of certain figures: Gertrude T. van Ysselsteyn, "Wilhelmus: Naar aanleiding van Frances A. Yates, The Valois Tapestries" (Wilhelmus: In Pursuance of Francis A. Yates, The Valois Tapestries), in De Bloeitijd . . .: L'Age d'or de la tapisserie flamande. Colloque international 1961 (Brussels, 1969), 329-86 (this is not very reliable because the author seems unfamiliar with the history of the Valois); and Barbara A. Heezen-Stoll, "Le prince infortune. Overwegingen met betrekking tot François-Hercule de Valois en de Valoistapijten, zijn relaties met de Nederlanden en Engeland" (The unlucky prince: François-Hercule de Valois and the Valois Tapestries: His Relations with the Netherlands and England), De Zeventiende Eeuw 6, no. 2 (1990): $1-46$ (this is much more rigorous than the former essay, but it has been overlooked by most authors).

10. "De son grand oncle le Pape Léon, et du magnifique le seigneur Laurens de Médicis." Cited in Yates, The Valois Tapestries, 53, n. 1.
11. "Le plus beau ballet qui fût jamais fait au monde." Cited in Yates, The Valois Tapestries, 67.

12. De Groër, "Les tapisseries des Valois," 126.

13. Ibid.

14. Charles IX died in 1574; thus, as there is no dead person represented in these tapestries, he is replaced here by his brother Henri III.

15. Yates, The Valois Tapestries, 73.

16. The traditional titles for the tapestries are used here.

17. E.g., in the Carrousel des chevaliers bretons et irlandais à Bayonne (steps) or again in the Fête aux Tuileries en l'honneur des ambassadeurs polonais (a border parallel with the lower edge of the tapestry).

18. This compositional principle already appears in the drawings by Antoine Caron that have been linked to the tapestries. See n. 39. In the history of painting, it is Alberti who invented the device of placing between the scene depicted and the spectator a linking figure who at the same time faced the viewer and designated the interior of the painting. On this linking figure, or admonisher, see Pierre Georgel and Anne-Marie Lecoq, chap. 18, "Donner à voir," in La peinture dans la peinture (Paris, 1987), 179-81. "J'aime qu'il y ait parmi les protagonistes de la scène, un admoniteur qui nous montre ce qui ce passe ou qui, de la main, nous invite à voir, ou une figure menaçante, au visage courroucé et au regard tourmenté, qui cherche à nous empêcher d'aller vers eux, ou quelqu'un qui nous révèle un danger ou une chose merveilleuse dans la scène, ou qui t'invite à pleurer ou à rire avec eux." Leon Battista Alberti, Della pittura, ed. C. Grayson (Rome, 1975), 72 (chap. 42).

19. Victor I. Stoichita, L'instauration du tableau: Métapeinture à l'aube des temps modernes (Paris, 1993; 2nd ed., Geneva, 1999: 17-34) calls "images dédoublées" (images divided into two, background and foreground).

20. On the representation of royalty, see Brassat, Tapisserien und Politik, 71-75. On the genealogical series, such as the Généalogie de la maison de Nassau delivered between 1530 and 1533 to Henri III de Nassau (known through watercolor drawings attributed to Bernard van Orley); the tapestries of the Ottheinrich family, Palatinate elector (around 1535; Heimatmuseum in Neuburg an der Donau and Bayerisches Nationalmuseum in Munich); the so-called "des Croy" tapestry in which the dukes of Saxony (including Jean-Frédéric the Magnanimous, one of the leaders of the League of Schmal- 
kalden) and the dukes of Pomerania appear at the foot of a chair where Luther preaches (woven in 1554 at Stettin for Philip I of Pomerania; ErnstMoritz-Universität de Greifswald, Germany); and the Généalogie des rois du Danemark (1581-1585; Château de Kronborg, Denmark): see esp. Rotraud Bauer, "Flämische Weber im deutschsprachigem Raum," in Flemish Tapestry Weavers Abroad: Emigration and the Founding of Manufactories in Europe. Proceedings of the International Conference held at Mechelen, October 2-3, 2000, ed. Guy Delmarcel (Louvain, 2002), 85-88; Vibeke Woldbye, "Flemish Tapestry Weavers in the Service of Nordic Kings," in ibid., 94-95; Hanns Hubach, "Tapisserien im Heidelberger Schloss. 1400-1700. Grundzüge einer Geschichte der ehemaligen Sammlung der Pfälzer Kurfürsten," in Carla Fondrey, et al., Tapisserien: Wandteppiche aus den staatlichen Schlössern Baden-Württembergs (Schätze aus unseren Schlössern. Eine Reihe der Staatlichen Schlösser und Gärten Baden-Württemberg, vol. 6 , Weinheim, Germany, 2002), 98-103; and Hanns Hubach, "'mit golt, silber und seyd kostlichst, erhaben, feyn und lustig gemacht': Pfalzgraf Ottheinrich und die Bildteppichproduktion in Neuburg 1539-1544/45," in Von Kaisers Gnaden. 500 Jahre Pfalz-Neuburg, exh. cat., ed. Suzanne Bäumler, Evamaria Brockhoff, and Michael Henker (Neuburg-on-the-Danube: Schloss Neuburg) (Augsburg, 2005), 174-78 and cat. entries.

21. On the programming of Renaissance festivals, see Jean Jacquot, ed., Les Fêtes de la Renaissance (Paris, 1956-1975); and Strong, Les Fêtes de la Renaissance.

22. Ivan Cloulas, Catherine de Médicis (Paris, 1979), 379-81.

\section{Ibid., 389-92. See also n. 31.}

24. Catherine de Médicis had tried to negotiate a marriage with a daughter of the king of Sweden, which would perhaps have helped to keep Poland.

25. The man holding a mask in his right hand, behind Henri III, is placed here to explain the meaning of the disguise in the scene in the background, where there is a cortege of knights, including at the left foreground two disguised as Amazons as well as a barbarian with a quiver full of arrows. This disguising as women was sometimes practiced during festivities. Brantôme was careful to note that the knights' faces were masked; cited by Ivanoff, "Les fêtes à la cour des derniers Valois," 102.

26. "Où la Royne ma mère disposa tout à l'entour de grandes niches, et dans chacune une table ronde à douze personnes." Cited in Yates, The Valois Tapestries, 58 .

\section{Yates, The Valois Tapestries, 57.}

28. Ibid., 61. The marriage of Catherine's daughter Marguerite de Valois and the Protestant Henri de Navarre resulted in the end of the policy of reconciliation pursued since the Peace of SaintGermain (1570). The wedding was celebrated from August 18 to 21, 1572. During the night of August 23-24 (on the eve of St. Bartholomew's Day, August 24), however, the assassination of the Protestant leaders, including Gaspard II de Coligny, directed by the Guises and the royal troops, led to general rioting by the bourgeoisie and the fanaticized lower classes which attacked all of the Protestants then in Paris for the wedding. The massacre, which continued in the provinces until October, claimed an estimated 3,000 in Paris, and 70,000 in all of France, and reignited the civil war between Catholics and Protestants.

29. In the elephant in the Mascarade, Jardine and Brotton (Global Interests, 128-31) see an expression of ancient military power and imperial triumphalism inherited from François I. The elephant is used to suggest the strength of the French Crown in one of the frescoes in the Galerie François I at Fontainebleau. The French monarch had commissioned the conquest tapestry of the History of Scipio, a work featuring elephants that was still used by the Valois for ceremonies, festivals, and more specifically for the festivals at Bayonne. The Mascarade could have been derived from the Scipio tapestry Bataille de Zama.

30. L'Europe humaniste, exh. cat. (Brussels: Palais des Beaux-Arts, 1955), no. 357.

31. François-Hercule d'Alençon, who dreamed of a crown, was cruelly mocked by his brother Henri III, and the prince fled on September 15, 1575. Catherine de Médicis thought that d'Alençon was going to revive the troops of the Malcontents, and she tried to catch up with him. She reached an accord, the Edict of Beaulieu (May 7, 1576), called the "Peace of Monsieur," because all clauses were so favorable to d'Alençon and his allies.

32. See Appendix for the various identifications proposed for the figures in the foreground.

33. On the lessons Catherine de Médicis gave to her children, see esp. Janine Garrisson, Catherine de Médicis: L'impossible harmonie (Paris, 2002), 73-77.

34. Pascal-François Bertrand, "Les ateliers secondaires de tapisserie en France: Méthode d'analyse," in Regards sur la tapisserie, ed. Guy Massim-Le Goff and Étienne Vacquet, Actes des Journées d'Étude de l'Association des Conservateurs des Antiquités et Objets d'Art de France, Angers, May 18-20, 2000 (Arles, 2002), 25-42; and idem, "Les tapissiers flamands en France aux XVe et XVIe siècles," in Flemish Tapestry Weavers Abroad, ed. Delmarcel, 185-201. It should be recalled that it was under analogous circumstances that a Brussels workshop was solicited in the seventeenth century when the weaving of the Vie de la Vierge destined for the choir of Notre-Dame de Paris was redone. See La Vierge, le roi et le ministre. Le décor du choeur de Notre-Dame de Paris au XVIIe siècle, exh. cat., ed. Nicolas Sainte-Fare-Garnot (Arras: Musée des Beaux-Arts, 1996).

35. Bibliothèque Nationale de France, MS. Fr. 306. A large extract was published by Adrien-Léon Lacordaire [often misidentified as Antoine-Louis Lacordaire], Notice historique sur les manufactures impériales de tapisseries des Gobelins et de tapis de la Savonnerie (Paris, 1853), 23-25.

36. Valérie Auclair ("De l'estampe à la chronique contemporaine: L'histoire de la Royne Arthemise de l'invention de Nicolas Houel," Journal de la Renaissance 1 [2000]: 155-88) showed that Houel still had not offered the queen his manuscript in 1580 and therefore the set could not have been woven before that. The project of the Histoire d'Artémise was only put on the loom beginning in 1600 , the year after the death of Antoine Caron, who had provided the models. It thus appears to be a posthumous hommage to the painter, as were the engravings made after his drawings that illustrated the Images de Philostrate, published in Paris in 1614. See Pascal-François Bertrand, Les tapisseries des Barberini et la décoration d'intérieur dans la Rome baroque (Turnhout, 2005), 103-12.

\section{Ehrmann, Antoine Caron, 84-104.}

38. Most of the drawings for the Histoire d'Artémise were attributed to Antoine Caron, and several sheets were attributed to the Bellefontaine artists Nicolò dell'Abate, his son Giulio Camillo, and Baptiste Pellerin. See esp. the entry on Caron by Cécile Scaillierez, in the Allgemeines Künstlerlexikon, vol. 16 (Munich and Leipzig, 1997), 511-14. The most common dating of the drawings is that of 1562-1571, but, according to Jean Ehrmann, "Antoine Caron: Tapisserie et tableau inédits dans la série de la reine Artémise," Bulletin de la Société de l'Art Français (1964): 31-32, they were probably executed over a period of about fifteen years.

39. The six extant preparatory drawings for the eight tapestries of the Fêtes des Valois are generally dated to the end of the reign of Charles IX, around 
1570-1574 (Ehrmann, "Dessins d'Antoine Caron"; Yates, The Valois Tapestries, pls. IX-XI; Ehrmann, Antoine Caron, 189-200). Are they projects for a painted or woven cycle celebrating only the festivals? Are they drawings that were re-used and to which someone added the portraits in the foregrounds at the last minute? Nothing permits a more precise account of the commission. As in every weaving commission, these transpositions were subject to more or less major modifications, which previous authors have attempted to detect. Take as an example the drawing said to represent the Départ pour la chasse (Louvre), but which shows instead the Cour nomade de Charles IX quittant le château d'Anet (Monique Châtenet and Françoise Boudon, "Les logis du roi de France au XVIe siècle," in Architecture et vie sociale: L'organisation intérieure des grandes demeures à la fin du Moyen Âge et à la Renaissance, ed. Jean Guillaume, Actes du colloque, Tours, June 6-10, 1988 [Paris, 1994], 65, fig. 1, a subject that can also be found in the tapestry entitled Départ en voyage de la Cour.) According to Nicolas Ivanoff, the subject of the drawing for that tapestry would be the departure for the "Grand Voyage de France" that Catherine undertook with her son in 1564-1565 to appease tensions, to introduce the young king to his subjects, and to reaffirm the monarchy whose authority had been weakened by a first religious war (Nicolas Ivanoff, "Les fêtes à la cour des derniers Valois d'après les tapisseries flamandes du Musée des Offices à Florence," Revue du XVIe siècle 19 [1932. 1933]: 96-122). Yates sees in these festivities the departure of the duc d'Anjou (the future Henri III) for his kingdom in Poland (1573). In both cases, the Court did not leave from Anet. These chrono- logical unlikelihoods, which are not out of the ordinary, will not be belabored, especially where the glorification of a person or a family is concerned. The episode depicted more likely commemorates the 1567 arrival of the king at the château d'Anet, which belonged at the time to the duc d'Aumale, son-in-law of Diane de Poitiers, governor of Burgundy, and Grand Veneur (chief huntsman) of France (De Groër, "Les tapisseries des Valois," 126). Let it also be remembered that Catherine de Médicis passed through Anet in 1562 on her way to the siege of Rouen, without visiting Diane de Poitiers, disgraced after the death of Henri II. It should be added that it was at Anet that François I signed the marriage contract uniting the future Henri II to Catherine de Médicis. The date was April 24, 1531-and therefore long before the castle was rebuilt by Philibert de l'Orme beginning in 1546 .

40. Coming from Ghent, de Heere took his apprenticeship in the studio of Frans Floris, where he taught himself the production of cartoons for stained-glass windows and tapestries. Around 1560, he came to work at Fontainebleau, where, linked to the service of Catherine de Médicis, he executed tapestry cartoons (now lost). Shortly thereafter, he returned to his native city. A Protestant fleeing the persecutions of the tyrannical Spanish regime in Holland, he found refuge in England beginning in 1567 . He finally appeared as a painter to the Stadtholder of Holland.

41. Yates, The Valois Tapestries, 120, 126.

42. As mentioned in the text, the meaning of the hangings was lost by 1589 , at least for the recorder of the inventory of goods belonging to Christine de Lorraine in Florence.

43. Ivanoff, "Les fêtes à la cour des derniers Valois," 113.

44. Ibid., 114 .

45. Van Ysselsteyn, "Wilhelmus," 331.

46. Ibid.

47. Ivanoff, "Les fêtes à la cour des derniers Valois," 103.

48. Yates, The Valois Tapestries, 96, 99-101.

49. Van Ysselsteyn, "Wilhelmus," 331.

50. Yates, The Valois Tapestries, 96-98.

51. Van Ysselsteyn, "Wilhelmus," 331.

52. Ivanoff, "Les fêtes à la cour des derniers Valois," 117.

53. Heezen-Stoll, "Le prince infortune," 22.

54. Yates, The Valois Tapestries, 8-9.

55. De Groër, "Les tapisseries des Valois," 130.

56. Ivanoff, "Les fêtes à la cour des derniers Valois," 98-99.

57. Ibid.

58. Yates, The Valois Tapestries, 76-78.

59. Van Ysselsteyn, "Wilhelmus," 332.

60. De Groër, "Les tapisseries des Valois," 129.

61. Heezen-Stoll, "Le prince infortune," 27. 